\title{
ROLES OF JOB SATISFACTION IN ENSURING QUALITY OF WORKING LIFE
}

\author{
ROZAINI ROSLI \\ NORAILIS AB. WAHAB \\ Faculty of Economics and Muamalat \\ Universiti Sains Islam Malaysia
}

\begin{abstract}
At present many companies around the world are struggling to meet the challenges presented by the organization's global trends. The workforce has been continuously reminded of the competitiveness and increasing productivity in ensuring better working life. Not forgetting to balance the routines, job satisfaction needs also to be deliberated in any organization. In the current business scenario, the workforce in Malaysia has often been called to acquire core competencies and maintain their competitiveness in a liberalized and globalized market. Further, with the implementation of various policies pertinent to employment including the retirement age and minimum wages, the workplace is no more a pleasant place. Workers need to be more innovative, creative and talented to sustain employment. For such reasons, this paper attempts to examine the relationship between organizational support and job satisfaction in the insurance industry. The results showed that satisfaction with the job $(M=3.68)$; successful people, directed or influenced by its own commitment to achieve organizational goals $(M=3.55)$; know and understand the policies and processes to do their job better $(M=3.54)$. This result is important in that it clearly shows that the relationship between job satisfaction and organizational support are intertwined and closely related to organization performance. This paper proposed a practical model that helps management or decision-makers to highlight the most influential factors that influence the quality of employees' working life in their organizations.
\end{abstract}

Keywords: Job satisfaction, quality of working life, insurance industry.

\section{Introduction}

Nowadays the business environment is changing very fast. The changes in technology like e-business and e-commerce have created a quantum leap information availability and control of doing business. 
With the impending move toward globalization and liberalization of the economy, organizations should prepare and cope with the rapid changes in the business dynamics. Each organization must submit and vary the demands of changes in the workplace environment. Changes within an organization take place in response to business and economic events and to processes of managerial perception, choice, and actions where managers see events taking place that indicate the need for change. According to Thomas (2000) the corporation had 'delivered', throwing off entire levels of management and it was 'disaggregated', ridding itself of its extraneous operations; it embraced 'flexibility', making it easier to replace career workers with (zero-benefit) temps and 'disinter mediated' with new technology system. Organizations are continuously looking for new ways of doing business in order to meet the challenges of today's dynamic business environment. Given the amount of time and energy people expand at the workplace, it is important for workers to satisfy their entire life. Workers perceived that different aspects of the treatment would actually influence organizational support and consequently the ability to influence is how the workers interpret the motives underlying the treatment by the organization (Eisenberger, Huntington, Hutchison \& Sowa, 1986). Organizational leaders would have to seriously look into addressing organizational-supported policies and programmes in an effort to preserve an acceptable level of perceived organizational support (Rhoades \& Eisenberger, 2002).

Likewise, the Malaysian government in unveiling Vision 2020 in the early 1990s has adopted cultures and life-styles of other countries such as Japan to balance economy and social life. (Mahathir Mohamad, 1991). He further mentioned that since independence fifty-six years ago, Malaysia has given the highest priority to the development of the country in all dimensions including the quality of working life (QWL). Quality working life is a philosophy and a set of principles, which hold people in the most important resource in the organization as they are trustworthy, responsible and capable of making valuable contributions and are treated with dignity and respect.

In realizing the aspiration of the country and a happier working life, Malaysia had carried out researches in 2012 regarding the perception of managers about their workplace and how they attribute the changes in the evolving patterns of work and organizational structures that affect their working and non-working lives (Economic Report 2011/2012). The researches mainly explored four themes such as perceptions of the organization and workplace; management and 
leadership styles, working hours and the effects working hours have on managers, and the strategic performance of organizations.

Table 1

Worldwide Quality of Life Index

\begin{tabular}{lccccc}
\hline Country & Score & Rank & Country & Score & Rank \\
\hline Ireland & 8.333 & 1 & Costa Rica & 6.624 & 35 \\
Switzerland & 8.068 & 2 & Malaysia & 6.308 & 36 \\
Norway & 8.051 & 3 & Hungary & 6.534 & 37 \\
Luxembourg & 8.015 & 4 & Israel & 6.488 & 38 \\
Sweden & 7.937 & 5 & Brazil & 6.470 & 39 \\
Australia & 7.925 & 6 & Thailand & 6.436 & 40 \\
\hline
\end{tabular}

Source. The Economic Intelligent Unit (2005).

According to Table 1, Malaysia was ranked at number 36 across 111 countries. The composite index is a single measure to reflect the multidimensional development process at different points of time. The development of MQLI follows a similar concept used in internationallyknown indices such as the Human Development Index by the United Nations Development Programme (UNDP) and the Quality of Life Index by the Economist Intelligence Unit. One of the components highlighted in the MQLI is Working Life Conditions, which looks at the working environment in Malaysia such as the unemployment rate and trade disputes. Besides, satisfaction of workers needs thorough resources, activities and outcomes stemming from participation in the workplace as measured through quality of the working life index. As a consequence to the satisfied and conducive working environment, quality work life enhances business performance.

According to the Randstad Workmonitor Report for Q2 2012, three in five (62 per cent) employees in Malaysia consider a good salary as more important than job satisfaction. It shows that this figure is among the highest from a global survey of 32 countries, with respondents across the region placing less emphasis on remuneration in China (55 per cent), Japan (52 per cent), Singapore (51 per cent), Australia (35 per cent) and New Zealand (32 per cent). The survey of 405 employees in Malaysia also found that two in five (42 per cent) would quit their jobs if there were no more room for personal 
development. This figure is even higher (62 per cent) for workers aged $18-24$. Younger workers are generally more ambitious in their climb up the corporate ladder. They are more likely to change jobs, even if it means moving overseas, in order to gain more work experience, as well as higher pay. In this aspect, business leaders need to recognize the importance of offering opportunities for training and career development to help this group enhance their professional skills and stay loyal to their organization.

The overall objective of the insurance industry is to build an efficient, effective and stable financial sector that supports both the needs of the real economy and the socio-economic objectives of the country. The aim is also to build at the core of the financial system, strong domestic institutions that provide Malaysian consumers with worldclass products and services, while meeting international commitment to liberalization of the sector in the medium-term. Consequently, there are competitions between companies to attract and retain quality human resource in order to be ahead of their competitors in a particular industry. On this backdrop, quality of working life has emerged as one of the most important aspects of a job that ensures the long-term association of the employees with the organization. Therefore, this paper aims to confirm the influence of job satisfaction on the quality of working life among players in the Malaysian insurance industry.

\section{Literature Review}

\section{Job Satisfaction}

Job satisfaction represents a combination of positive or negative feelings that workers have towards their work. It is a complex variable and is influenced by situational factors of the job as well as the dispositional characteristics of the individual (Sharma \& Ghosh, 2006). According to the dictionary, job satisfaction is an act of satisfying, fulfillment, and gratification. It is the state of being satisfied or contended. According to Weiss (2002) job satisfaction is an attitude towards a job taking into account feelings, beliefs and behaviours. It also refers to how well a worker provides the job to the fulfillment of a need or want, or how well it serves as a source or means of enjoyment. According to Rose (2001), worker is intrinsically satisfied if he receives no apparent reward except the activity itself, while extrinsic satisfaction is defined as the opposite concept (that is, 
worker is extrinsically satisfied if he receives monetary compensation or other material rewards to modify his behaviour). Much research has been conducted into ways of improving the job satisfaction of workers in various sectors of the Malaysian economy, including the academic sector (Wong \& Teoh, 2009; Noordin \& Jusoff, 2009). Locke (1976) described job satisfaction as "a pleasurable or positive emotional state resulting from the appraisal of one's job or job experiences". A survey on "Quality of working life in the Czech Republicœ was carried out by the European Foundation for the Improvement of Living and Working Conditions it and reported in 2006 that the satisfaction of workers depends upon the quality of the people one works with, providing good service to customers/ colleagues, base pay, nature of work, being treated with respect, work-life balance, learning and development, long-term career potential, bonuses, flexible working arrangements, promotion opportunities and benefits.

There are several misleading notions that exist about job satisfaction. One such fallacy is that a happy employee is a productive employee (Syptak, Marsland, \& Ulmer, 1999). Research has offered little support that a happy employee is productive; furthermore, some research has suggested that causality may flow in the opposite direction, from productivity to satisfaction (Bassett, 1994). Another fallacy is that pay is the most important factor in job satisfaction. In reality, employees are more satisfied when they enjoy the environment in which they work (Berry, 1997). An individual can have a high paying job and not be satisfied because it is boring and lacks sufficient stimulation. In fact, a low-paying job can be seen as satisfying if it is adequately challenging or stimulating.

\section{Quality of Working Life}

The term originated from the concept of the open socio-technical system designed in the 1970s that helps to ensure autonomy in work, interdependence, and self-involvement with the idea of 'best-fit' between technology and social organizations. Although the open socio-technical system is a traditional concept, it assumes that optimal system performance and the 'right' technical organization coincide with those job conditions under which the social and psychological needs of the workers are satisfied (Belweg, 1976). According to Hackman and Suttle (1977) the concept and practice of quality working life is broad and diverse and many use this phrase in their own way. Beukema (1987) opined that employees are able to shape their jobs actively, in accordance with their options, interests and needs. It is the 
measure of power given by the management to employees to reshape their work. Rethinam and Ismail (2008) viewed that an organizational environment conducive for human work requires the creation of work conditions that can enhance the quality of worker's working life in the organization, and increase performance and productivity. In other words, the organizational environment must have the capacity to satisfy meaningfully worker's organizational and personal needs, and also the ability to shape organizational values.

According Whitener (2001) the potential workers on commitment and motivation will include selective hiring, appraisal, compensation, training and development activities. Organizational support is defined as the workers' global beliefs with regards to the extent to which the organization values their contributions and cares about their wellbeing (Eisenberger et al., 1986). Since workers make attributions about the organizations, they can perceive their treatment as whether the organization favours or disfavours them. Attribution processes of workers are used to infer organizational support. These attribution processes are based on experience concerning the caring or noncaring intentions of policies, norms, or actions of an organization that affect workers (Eisenberger et al., 2001).

\section{Table 2}

Wellbeing, Reward, Equity and Value

Dimension and Item

$\%$ Agreed

Health and well-being

My well-being is taken seriously in this organization.

Many people in this organization feel stressed out.

Many people have a sense of powerlessness in this organization.

Many people feel under pressure to work beyond their contract and specified hours.

I have witnessed bullying in this organization.

Reward, equity and value

This organization will provide me with a secure job for the foreseeable future.

Creativity is rewarded in this organization.

Employees are treated as this organization's most important asset. 


\begin{tabular}{lc}
\hline Dimension and Item & \% Agreed \\
\hline Poor performance is quickly dealt with in this organization. & 66 \\
Compliance is rewarded in this organization. & 64.7 \\
I often feel that I am being exploited in this organization. & 32.7 \\
Employee are last to hear about changes that affect them. & 46 \\
\hline
\end{tabular}

Source. Preliminary Report, Malaysia Quality Work Life (2012).

The overall improvement in the economic development of the nation was also reflected in the increase in the quality of working life of the population at the state level. This is attributed to various strategies at the federal and state levels. In line with this, the Ninth Malaysia Plan (20062010) set out to achieve a stronger and more value-added economy, while giving substantial focus to socio-economic issues and uplifting the quality of life for all. As a consequence of the satisfied and conducive working environment, quality working life enhances business performance. As evidenced by the data in Table 2, 78 per cent of the respondents supported to the organization's commitment, 74.5 per cent of the respondents felt secure in their jobs. On the positive side, 62.8 per cent found that they were encouraged and rewarded for creative behaviour. However, at the same time, there was also a strong feeling (64.7 per cent), that their companies expected and rewarded them for compliance behaviour to the chain of command. This was indicative of the presence of a hierarchical structure.

It has been argued that the quality of working life affects the performance and commitment of employees in various industries, especially in the insurance industry (Huang et al., 2007). In general, the researches about quality working life have been on purpose on the individual situations of workers in the labourer environment, including individual behaviour and satisfaction (Limongi-Franca, 2004).

\section{Relationship between Job Satisfaction and Quality of Working Life}

Work is prevalent also because it occupies a large part of the available time of adults, and it has ramifications affecting virtually all other aspects of life (Strauss, 1974). Apart from the need for structure, there are, of course, a number of benefits obtained from participating in working life on behalf of the workers, such as sufficient economic return, job security, etc. However, there is the possibility that when such more or less lower level needs, as presented in Maslow's need- 
hierarchy, have been met, other outcomes from participation in working life will be more highly valued. Further, as Lawler (1973) has pointed out, job satisfaction is one measure of the quality of working life, also indicating that job satisfaction is important not only in and of itself, but also as an indicator of this broader concept.

Employers have prerogative power in the industrial relationship to keep workers from leaving and going to work for other companies. In other words, the "hiring and firing" concept is the discretion of the employers instead of having the responsibility to improvise the needs of workers. (Industrial Relation Act, 1967). This is true because of the great costs associated with hiring and retraining new workers. The best way to retain workers is by providing them with job satisfaction and opportunities for advancement in their careers. (Hammer, 2000). According Mark Parrott (2000) there is a straight line between worker satisfaction and customer satisfaction. If the workers are satisfied and happy with their jobs they are more dedicated to doing a good job and taking care of the customers that sustain the operation (Denton, 2000).

Retaining workers in an organization is a big challenge for the management levels. In this situation, if the organization fails to fulfill the workers' needs and the workers are not satisfied with their job, turnover will happen. It is proven by the study of Shultz and Schultz (1994), in which they concluded that it could be assumed that high job satisfaction is related to a worker's positive attitudes such as high job performance and low turnover. Some employers give less attention to the older or to the to-be-retired worker's job satisfaction (Cranny, Smith \& Stone, 1992).

\section{Methodology}

This paper employed the survey method by using self-administered questionnaires. In order to suit the objectives of the research these items were adapted from the standard application produced by the National Institute of Occupational Safety and Health (NIOSH, 2010) incorporated with Glaser (2005) and Moorhead and Griffin (2001). All items were keyed in the same direction and, therefore, the questionnaire might have been prone to response-style bias; in other words, always making choices in the middle area or choosing the alternative which is socially acceptable. In this case, all Cronbach alphas were above 0.64 and thus the reliability of measures could be 
considered as good. The scale suggested by Sekaran, (2006) was used to interpret the reliability coefficient. The Likert scale was used where respondents stated their degree of agreement ranging from strongly agree to strongly disagree. According to Cresswell (2003), Likert's method yields higher reliability coefficients than the interval scale. This approach was to determine the total score for each respondent on each store. It was important to use a consistent scoring procedure so that a high (or low) score consistently reflected a favorauble response.

This questionnaire was given to the respondents at the end of 2011 to 155 workers in insurance companies. 94 completed questionnaires were used in the analysis, which gave a usable rate of 60.7 per cent. The result of 0.945 from the reliability analysis, showed a strong interitem consistency reliability of the items measured. For the purpose of the study, the additional information needed was the sociodemographic status of the respondents. 34 per cent were executives while 66 per cent were non-executives. Overall, 48.7 per cent of all the respondents reported they were married at the time of the survey, 44.7 per cent reported as being single and a small percentage reported being divorced ( 6.4 per cent). For 45.7 per cent their tenure was around 10 to 19 years, for 23.4 per cent it was 0 to 3 years and only 13.8 per cent had more than 20 years tenure.

\section{Findings and Discussion}

Table 3 presents the mean and standard deviation for job satisfaction in the insurance company. These relatively high scores show that the respondents are satisfied with their jobs in the company (3.68 mean, $\mathrm{SD}=1.226$ ). Among the reasons are the positive effects of job satisfaction, organizational support and commitment to career development among the members of the profession.

Table 3

Mean and Standard Deviation for Job Satisfaction

\begin{tabular}{llcc}
\hline No. & \multicolumn{1}{c}{ Items } & Mean & $\begin{array}{c}\text { Standard } \\
\text { deviation }\end{array}$ \\
\hline 1. I am satisfied with my job overall. & 3.68 & 1.226 \\
2. I know where to go and who to contact to help me & 3.12 & 1.279 \\
& & \\
\hline
\end{tabular}

(continued) 


\begin{tabular}{|c|c|c|c|}
\hline No. & Items & Mean & $\begin{array}{l}\text { Standard } \\
\text { deviation }\end{array}$ \\
\hline 3. & $\begin{array}{l}\text { My companies encourage teamwork and } \\
\text { professionalism. }\end{array}$ & 3.27 & 1.234 \\
\hline 4. & $\begin{array}{l}\text { I know and understand the policies and processes } \\
\text { in order to do my job well. }\end{array}$ & 3.54 & 1.089 \\
\hline 5. & $\begin{array}{l}\text { I have the experience and knowledge to perform } \\
\text { my role efficiently. }\end{array}$ & 2.06 & 1.085 \\
\hline 6. & $\begin{array}{l}\text { My companies encourage meeting the challenges } \\
\text { of the task and finding a better prospect. }\end{array}$ & 2.88 & 1.364 \\
\hline 7. & $\begin{array}{l}\text { My management is supportive, responsive, and } \\
\text { concerned about the personal concerns and needs } \\
\text { of those who work under them. }\end{array}$ & 1.97 & 1.635 \\
\hline 8. & My management is encouraging and motivating. & 3.37 & 1.027 \\
\hline 9. & $\begin{array}{l}\text { I trust that all the outstanding issues will be } \\
\text { resolved over time. }\end{array}$ & 3.10 & 1.293 \\
\hline 10. & $\begin{array}{l}\text { I am committed to doing my part at improving } \\
\text { the working relationship in the organization. }\end{array}$ & 2.57 & 1.309 \\
\hline 11. & $\begin{array}{l}\text { People are managed, directed, or influenced by } \\
\text { their own commitment to achieving the goals of } \\
\text { the organization. }\end{array}$ & 3.55 & 1.280 \\
\hline 12. & $\begin{array}{l}\text { If rules, systems, or procedures get in the } \\
\text { way, people tend to ignore or by-pass them to } \\
\text { accomplish their tasks or perform their jobs better. }\end{array}$ & 2.97 & 1.419 \\
\hline 13. & $\begin{array}{l}\text { The salaries we receive are as good as what other } \\
\text { organizations offer their workers. }\end{array}$ & 3.37 & 1.329 \\
\hline 14. & $\begin{array}{l}\text { Workers are expected to be good team-workers, } \\
\text { supportive and cooperative, who get along well } \\
\text { with others. }\end{array}$ & 3.09 & 1.379 \\
\hline 15. & $\begin{array}{l}\text { Tracking and feedback are carried out as agreed } \\
\text { during the planning phase. }\end{array}$ & 2.79 & 1.423 \\
\hline 16. & $\begin{array}{l}\text { The only feedback that I receive is when I deliver } \\
\text { poor performance. }\end{array}$ & 2.96 & 1.253 \\
\hline
\end{tabular}

Table 4 summarizes the quality of working life scores. However, they indicate moderate satisfaction towards health care benefits, working environment, flexible working hours, relationship with co-workers and superiors as well as the opportunity to work independently. 
IJMS 20 (2), (129-144) (2013)

Table 4

Mean and Standard Deviation for Quality of Work Life

\begin{tabular}{|c|c|c|c|}
\hline No. & Items & Mean & $\begin{array}{l}\text { Standard } \\
\text { deviation }\end{array}$ \\
\hline & My job requires that I keep learning new things. & 2.72 & 1.427 \\
\hline 2. & My job requires that I work very fast. & 2.42 & 1.485 \\
\hline 3. & I get to do a number of different things on my job. & 2.63 & 1.551 \\
\hline 4. & I have too much work to do everything well. & 2.73 & 1.340 \\
\hline 5. & On my job, I know exactly what is expected of me. & 2.99 & 1.412 \\
\hline & My job lets me use my skills and abilities. & 3.16 & 1.256 \\
\hline 7. & At the place where I work, I am treated with respect. & 2.50 & 1.430 \\
\hline 8. & I trust the management at the place where I work. & 2.50 & 1.597 \\
\hline & $\begin{array}{l}\text { The safety of workers is a high priority with the } \\
\text { management where I work. }\end{array}$ & 2.95 & 1.175 \\
\hline 10. & $\begin{array}{l}\text { There are no significant compromises or shortcuts } \\
\text { taken when worker safety is at stake. }\end{array}$ & 2.89 & 1.267 \\
\hline & $\begin{array}{l}\text { Where I work, employees and management work } \\
\text { together to ensure the safest possible working } \\
\text { conditions. }\end{array}$ & 3.09 & 1.341 \\
\hline & $\begin{array}{l}\text { The safety and health conditions where I work are } \\
\text { good. }\end{array}$ & 4.29 & .882 \\
\hline 13. & I am proud to be working for my employer. & 4.43 & .911 \\
\hline 14. & $\begin{array}{l}\text { Conditions on my job allow me to be about as } \\
\text { productive as I could be. }\end{array}$ & 4.14 & .905 \\
\hline 15. & $\begin{array}{l}\text { The place where I work is run in a smooth and } \\
\text { effective manner. }\end{array}$ & 4.03 & 1.032 \\
\hline & $\begin{array}{l}\text { Workers need strong trade unions to protect their } \\
\text { interests. }\end{array}$ & 4.33 & .782 \\
\hline
\end{tabular}

The results also show relatively high scores. The need for unions obtained the highest score $(\mathrm{M}=4.33, \mathrm{SD}=0.782)$. Only few of these factors received scores above four (satisfied) and these may imply moderate to low-level satisfaction towards other job-related aspects. It is also noted that among the 16 items, the job requirement to work fast among the staff has the lowest score $(\mathrm{M}=2.42, \mathrm{SD}=1.485)$. Based on the findings, the respondents are particularly dissatisfied with most of the job-related aspects. 
Figure 1 indicates that married people are relating to adequate work of life. The married people are able to satisfy important personnel needs through their experience of the organization's extrinsic traits of jobs: wages and salaries, incentives, facilities and other benefits that are essential to maintain quality working life. The Pearson correlations results prove that there is a strong relationship between job satisfaction and the employee's quality of working life (.926, significant at 0.01 level; 2 - tailed). The contribution of meaningfulness, pessimism and autonomy elements to job satisfaction is cognitive and has a relationship with job satisfaction (Speitzer et al., 1997).

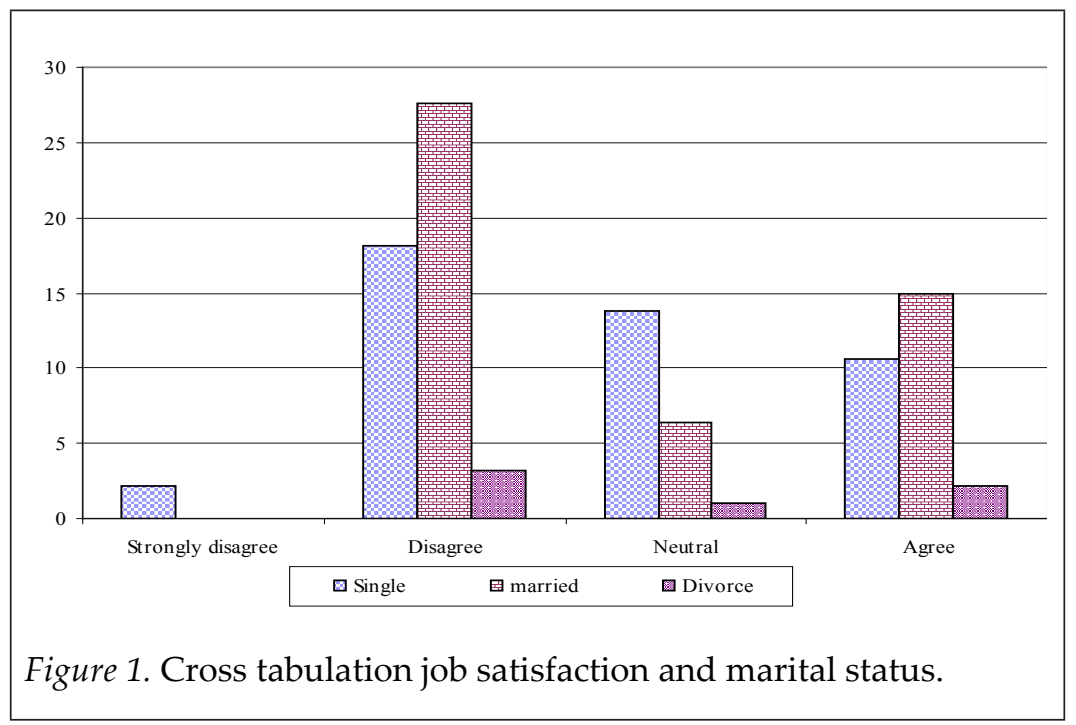

It appears those married groups want to achieve a new kind of balance between work and various dimensions of their lives. The married people emphasize life dimensions related to work; thus indicating the importance to balance their personal life and leisure in the phase of social development for working life balance. These findings are consistent in the work context, that requires a person to be exposed to highly autonomous decision-making in the workplace which would result in higher work-family enrichment (Grzywacz, 2002).

The most significant findings were the differences in the workers' viewpoints based on their tenure. Figure 2 shows that the workers' dissatisfaction increased with age. There were significant differences between young workers (aged under 25 years) and older workers (aged 45 years and above). Older workers were also more likely to 
have higher levels of dissatisfaction with the amount of work they had to do, their career prospects and their levels of pay relative to other workers doing similar work. The survey found that job satisfaction was the extraordinary increase in female participation when it came to balancing working and family life. It shows that those respondents who had 20 years and above experience had low satisfaction compared to other tenures.

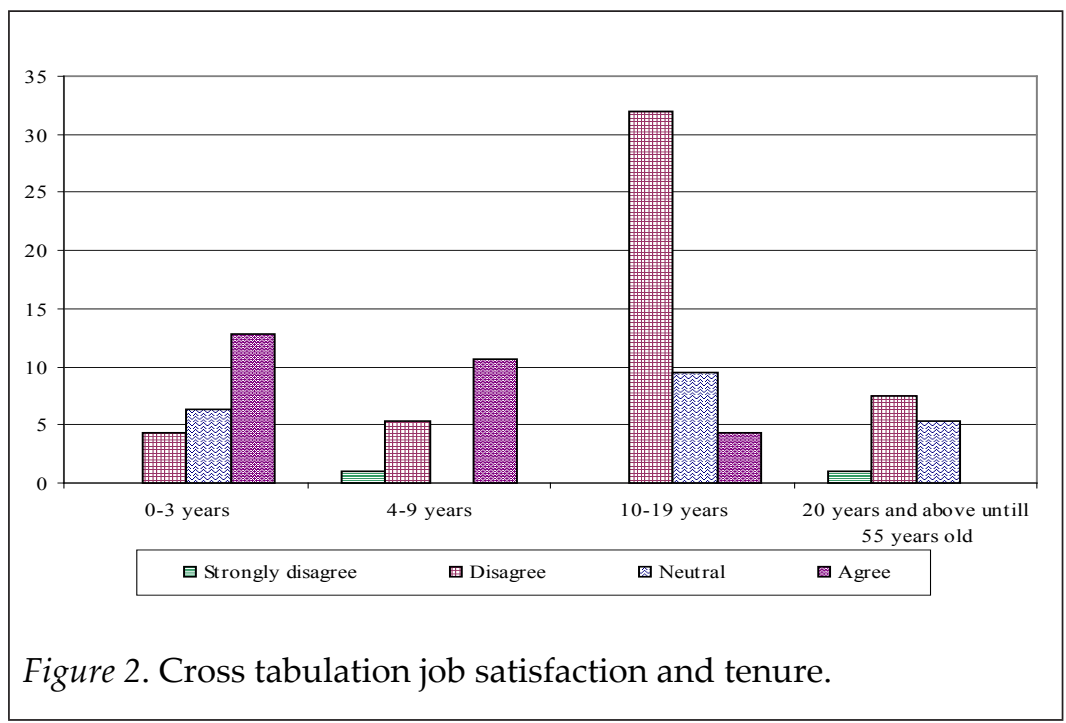

\section{Conclusion}

Past studies proposed management to make adjustments on their current policies and procedures as an effort to retain workers from leaving the organization. The results of this survey are intended to assist decision-makers or the management in the insurance industry to review or to consider the support provided to the workers. Apparently job satisfaction relies on organizational support along with the workers' tenure of employment. In fact, the intended (PBUH) states:

"Work for Allah will see you work, so will his messenger and the believers, and then you will be returned to the work knows all that is hidden and the witness overall who will be telling you what you did "

(At Tawbah 105). 
Therefore, this study concerning job satisfaction and the quality of working life may assist the insurance industry to design strategies and policies that are attractive and beneficial to the workers to retain their best talent in the industry. Perhaps, this study could be extended to cover broader aspects of job satisfaction, organizational support and talent among the workforce across industries.

\section{References}

Bank Negara Malaysia. (1999). The Central Bank and the Financial System in Malaysia: A Decade of Change (1989-1999).

Bank Negara Malaysia Annual Report. (2001). The Financial Sector Master Plan.

Bank Negara Malaysia Annual Report. (2010). The Financial Sector Master Plan Sources: The Economic Intelligent Unit (2005).

Bank Negara Malaysia Annual Report. (2011). The Financial Sector Master Plan.

Bank Negara Malaysia Annual Report. (2012). The Financial Sector Master Plan.

Bassett, G. (1994). The case against job satisfaction. Business Horizons, $37,61-68$.

Brief, A. P. (1998). Attitudes in and around organizations. Thousand Oaks: Sage Publication.

Berry, L. M. (1997). Psychology at work. San Francisco: McGraw-Hill.

Beukema, L. (1987). Quality of reduction of working hours. In Suzanne, E.J. Arts, Ada Kerkstra, Jouke Van Der Zee, \& Huda Huyer Abu Saad (Eds.), (2001). Quality of working life and workload in home help services: A review of the literature and a proposal for a research model. Scandinavian Journal of Caring Society, 15, 12-24.

Bolweg, J. F.(1976). Job design and industrial democracy. International Series of Quality of Work Life. Leiden: Nijhoff Social Sciences Division.

Cranny, C. J., Smith, P. C., \& Stone, E. F. (1992). Job satisfaction: How people feel about their jobs and how it affects their performance. New York: Lexington Books.

Creswell, J. W. (2003). Educational research: Planning conducting and evaluating quantitative and qualitative research (2nd ed.). Upper Saddle River, N.J: Person Merrill Prentice Hall.

Denton, J. (2000). Using web-based projects in a systems design and development course. Journal of Computer Information Systems, $40(3), 85-87$.

Hammer, R. (2000). Winning program brings smiles to hotel's employees. Houston Business Journal, 36, 493-522. 
Huang, G., Niu, X., Lee, C., \& Ashford, S. J. (2007). Differentiating cognitive and affective job insecurity: Antecedents and outcomes. Journal of Organizational Behaviour, 33(6), 752-769.

Eisenberger, R., Huntington, R., Hutchison, S., \& Sowa, D. (1986). Perceived organizational support. Journal of Applied Psychology, 71, 500-507.

Eisenberger, R., Armeli, S., Rexwinkel, B., Lynch, P. D., \& Rhoades, L. (2001). Reciprocation of perceived organizational support. Journal of Applied Psychology, 86, 42-51.

Glaser, B. G. (2005). The grounded theory perspective III: Theoretical coding. Mill Valley, CA: Sociology Press.

Grzywacz, J. G., \& Marks, N. F. (2000). Reconceptualizing the workfamily interface: An ecological perspective on the correlates of positive and negative spillover between work and family. Journal of Occupational Health Psychology, 5, 111-126.

Lawler, E. E. (1973). Motivation in work organizations. Person: Prentice Hall.

Lawler, E. (1982). Strategies for improving the quality of work life. American Psychologist, 37, 66-73.

Limongi-França, A. C. (2004). Qualidade de vida no trabalho: QVT (2nd ed.). São Paulo: Atlas.

Locke, E. A. (1976). The supervisor as motivator: His influence on employee performance and satisfaction. Washington: Heath and Company.

Mahathir Mohamed (1991). Malaysia: The way forward. Kuala Lumpur: Biro Tatanegara, Jabatan Perdana Menteri, Malaysia.

Mahathir Mohamad. (2008). The way forward. Capaian daripada http:// www.pmo.gov.my

Malaysia Industrial Relation Act 1967.

Mark, P. (2000). Employee satisfaction. Do-It-Yourself Retailing, 15(8).

Ministry of Finance. (2011/2012). Economic Report Kuala Lumpur.

Moorhead, G., \& Griffin, R.W. (2001). Organizational behaviour (5th ed.). Boston: Mifflin.

NORA (National Occupational research Agenda). (2013). Organization of work team members: The changing organization of work and the safety and health of working people. Retrieved from http://www. cdc.gov

National Economic Advisory Council. (2010a). New Economic Model for Malaysia Part 1. Putrajaya, Malaysia: NEAC.

National Economic Advisory Council. (2010b). New Economic Model for Malaysia Concluding Part 2. Putrajaya, Malaysia: NEAC.

Noordin, F., \& Jusoff, K. (2009). Levels of job satisfaction amongst Malaysian academic staff. Asian Social Science, 5(5), 122-128. 
Preliminary Report, Malaysia Quality Work Life (2012).

Rethinam, G. S., \& Ismail, M. (2008). Constructs of quality of work life: A perspective of information and technology professionals. European Journal of Social Sciences, 7(1), 58-70.

Rhoades, L., \& Eisenberger, R. (2002). Perceived organizational support: A review of the literature. Journal of Applied Psychology, 87(4) August, 698-714.

Rose, M. (2001). Disparate measures in the workplace: Quantifying overall job satisfaction. A paper presented at the 2001 BHPS Research Conference, Colchester, United Kingdom.

Sekaran, U. (2006). Research method for business: A skill building approach (4th ed.). New York: John Wiley and Sons.

Schulz, R., Newsom, J. T., Fleissner, K., Decamp, A. R., \& Nieboer, A. P. (1994). The effects of bereavement after family caregiving. Aging and Mental Health, 1, 269-282.

Sharma, M., \& Ghosh, A. (2006). Perception of organizational climate and job satisfaction in nursing staff personnel. Indian Journal of Social Work, 67(3), 263-274.

Spreitzer, G. M., Kizilos, M. A., \& Nason, S. W. (1997). A dimensional analysis of the relationship between psychological empowerment and effectiveness, satisfaction, and strain. Journal of Management, 23(5), 679-704.

Strauss, G. (1974). Workers: Attitudes and adjustments. In J.W. Rosow (Ed.), The worker and the job. New Jersey: Prentice Hall.

Suttle, J. L. (1977). Improving life at work: Problems and prospects. In J. R. Hackman \& J. L. Suttle (Eds.), Improving life at work: Behavioral science approach to organizational change (pp. 1-29). California: Goodyear.

Syptak, J. M., Marsland, D.W., \& Ulmer, D. (1999). Job satisfaction: Putting theory into practice. Family practice management. Retrieved from http://www.aafp.org

Thomas, F. (2000). One market under god. London: Seeker and Warburg. Ucapan Bajet Tahun 2010. (2010). Retrieved from http://www.pmo. gov.my

Weiss, H. M. (2002). Deconstructing job satisfaction: Separating evaluations, beliefs and affective experiences. Human Resource Management Review, 12(2), 173-194.

Whitener, E. M. (2001). Do "high commitment" human resource practices affect employee commitment? A cross-level analysis using hierarchical linear modeling. Journal of Management, 27(5), 515-535.

Wong, E. S. K., \& Teoh, N. H. (2009). Case study of factors influencing jobs satisfaction in two Malaysian universities. International Business Research, 2(2), 86-98. 